\title{
Coastal forest management in the face of global change: Experience of four Asian countries
}

Luohui Lianga*, Evonne Yiü, Leni D. Camacho ${ }^{\mathrm{b}}$, Dixon T Gevañac, Thaung Naing Oo ${ }^{\mathrm{d}}$, Chaw Chaw Seine, Bixia Chen ${ }^{\mathrm{d}}$, Yuei Nakama ${ }^{\mathrm{d}}$, K. G. Saxena ${ }^{\mathrm{e}}$, Kazuhiko Takeuchi ${ }^{\mathrm{a}}$ and Akira Nagata ${ }^{\mathrm{a}}$

a United Nations University Institute for the Advanced Study of Sustainability(UNU-IAS), Jingumae, Shibuya-ku, Tokyo 15o-8925, Japan

$b$ University of the Philippines Los Baňos, Laguna 4031, Philippines

c Forest Research Institute, Yezin, Nay Pyi Taw, Myanmar

d University of the Ryukyus, Senbaru, Nishihara, Okinawa, 903-0213, Japan

e Jawaharlal Nehru University, New Delhi 110067, India

* Corresponding author. Email: liang@unu.edu

\section{ABSTRACT}

The cross-country study examined community-based coastal forest management and policies on how integrating coastal forest management with human settlement planning and local livelihoods needs can strengthen community resilience towards climate change impacts confounded with other global changes like land use-land cover change, biological invasion and loss of biodiversity and economic globalization and planetary changes like tsunami. The study sites, the Philippines, Myanmar, India and Japan are located in coastal areas vulnerable to typhoons in the Northwest Pacific or cyclones in the North Indian Ocean. Unlike a seawall which only has a protective function, the study found that in all study sites coastal forests not only protect local communities from floods, tides and storms but also provide a range of ecosystem services serving the interests of both local and global communities. It is also found that in all the study sites: 1) Forests have been long conserved and created around individual houses and the entire village as well for livelihood security; 2) Apart from embracing the protective function of forests, local communities have developed house architecture providing some protection from flooding and windstorm; 3) Forest belt and embankment are often integrated to check windstorms and flooding. The study recommends that coastal forest policymaking must take into account indigenous knowledge and local concerns along with scientific knowledge and global concerns for coastal forest management.

\section{KEYWORDS}

Coastal forest management, Disaster, Indigenous knowledge, Mitigation

DOI

https://doi.org/10.30852/sb.2017.70

\section{DATES}

Received: 27 July 2017

Published (online): 22 November 2017

Published (PDF): 9 May 2018

\section{INTRODUCTION}

Coasts are home to a large proportion of the global population, in particular in Asia. Coasts are experiencing the adverse consequences of hazards related to climate and sea level, and the impact of climate change is confounded with other global changes like land use-land cover change, biological invasion and loss of biodiversity and economic globalization and planetary changes like tsunamis. The tsunami-induced disasters following the earthquake of magnitude 9.0 in North-eastern Japan

\section{HIGHLIGHTS}

» Establishment of forests around houses and villages for protection and livelihoods

» Site-appropriate settlement planning in the face of coastal flooding and windstorm

» Integration of global and local benefits into coastal forest policymaking 
on 11 March 2011 alerted the world of the inadequacy of conventional infrastructure (such as cement seawalls) alone in protecting human life and property from natural disasters. Instead, "green infrastructure" of coastal forests, such as mangroves, beech forests, and plantations, should be included as part of an integrated approach to mitigate tsunami, storm surge, and climate change impacts induced disasters around coasts. Moreover, an integrated approach also offers a scope of synergizing local socio-economic and global environmental dimensions of sustainable development. Despite these benefits, in theory, there is little understanding about how the natural sub-system of forests and the human sub-system of settlement and infrastructure interact and how can they be integrated to adapt to climate change, in particular, from a cross-country comparative perspective (FAO, 2007; Alongi, 2008). Development of forest management systems complementing other ways of enhancing resilience such as sustainable agriculture, aquaculture, and fishery. First, the world after 1980 has lost mangrove forest, the keystone coastal forests from the point of biodiversity and ecosystem services, at a rate of 20 to $35 \%$ higher than other unique natural heritage of the planet like coral reef and tropical rainforests (FAO 2007) and $>75 \%$ of global mangrove area is covered in just 15 countries (Giri et al., 2011). Second, mangroves are naturally endowed with a significant potential of climate change mitigation by virtue of their ability to keep pace with sea level rise (Alongi, 2008) and conversion of low biomass/carbon system like salt marshes to mangrove forests sequestering carbon at a rate as high as $1.74 \mathrm{Mg} \mathrm{C} / \mathrm{ha}$ /year in recent decades (Alongi, 2012; Saintilan et al., 2014). In addition, mangrove forests provide regulating and supporting services, such as shoreline stabilization, coastal protection, water filtration and detoxification/pollution control, and habitat to unique biodiversity including numerous nutritious food and medicinal species. Third, the landless and poorest of the poor people in developing countries who depend on mangrove ecosystems for their livelihoods are often the most vulnerable communities to extreme events like tsunami, typhoons, and floods. Fourth, except for a few segments (Spalding et al. 2010), systematic management plans of coastal vegetation are lacking, and resource uses and regeneration practices guided by the indigenous knowledge and social network are still not intensively analyzed and documented

This article provides a summary of a cross-country (Philippines, Myanmar, India, and Japan) initiative aimed to (i) identify best practices of coastal forest management, integrating with planning of human settlements, agriculture, local livelihoods and climate change mitigation/adaptation, including indigenous knowledge; (ii) valuate barriers for up-scaling best practices, and effectiveness of coastal forest management policy through a bottom-up process; and (iii)recommend integrated approaches to harnessing forest regulating services in the planning of human settlements, agriculture and local livelihoods in coastal areas.

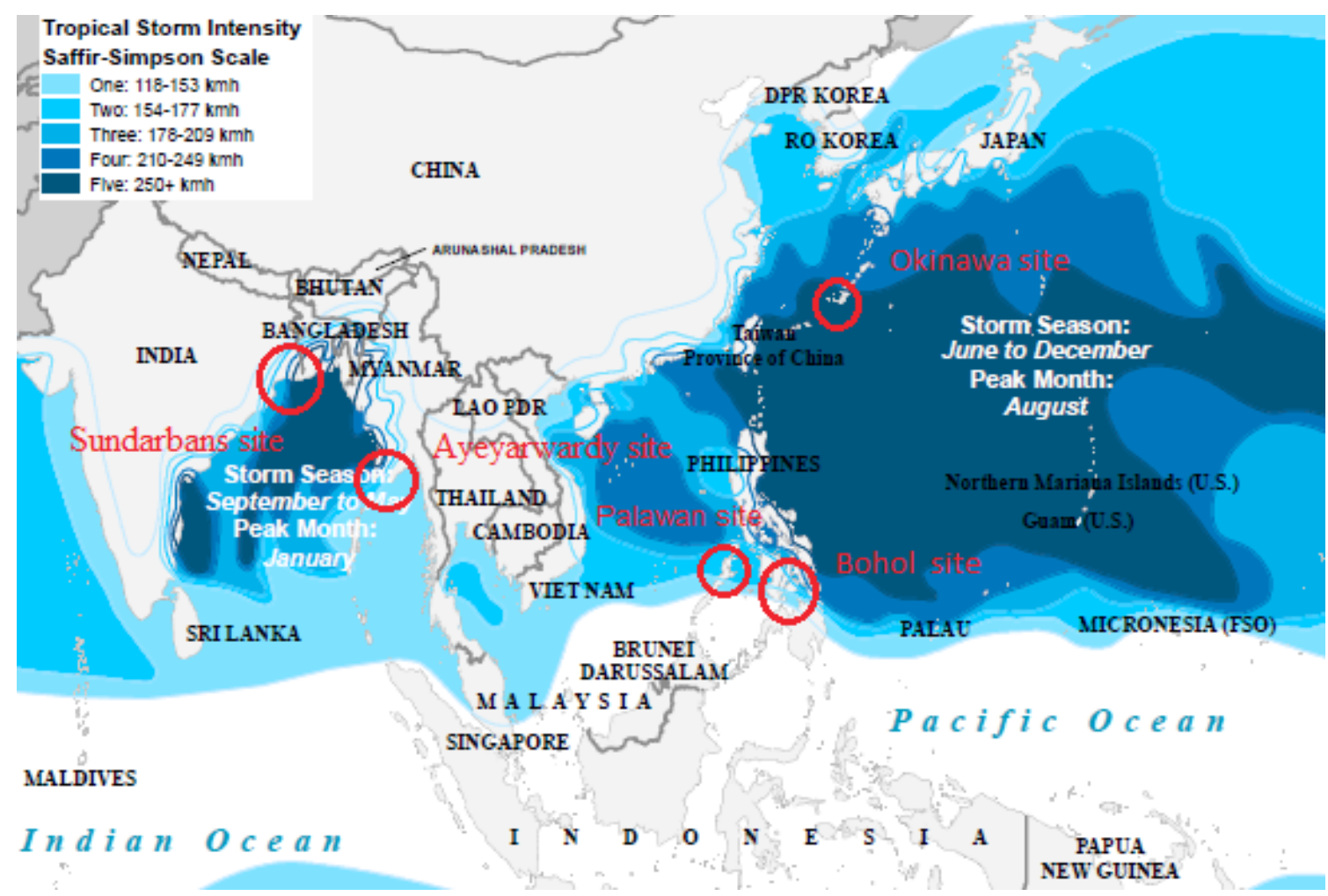

FIGURE 1 Location map of study sites based on the OCHA Relief Web map of Tropical Storm Risk in Asia-Pacific. 


\section{METHODOLOGY}

\subsection{Study Sites}

In order to compare lessons and experiences in management of coastal forests, especially mangrove forests, across Asia, the project selected two clusters of coastal communities vulnerable to typhoons in the Northwest Pacific, one each in the Philippines (Bohol and Palawan Province) and Japan (Okinawa Prefecture), and one cluster in Myanmar (Ayeyarwady Delta) vulnerable to tropical cyclones in the North Indian Ocean as study sites. The project was also enriched with an associated case study in Sundarbans, India around the Bay of Bengal, also vulnerable to tropical cyclones in the North Indian Ocean. Mangrove forests are dominant in the study sites of the Philippines, Myanmar, and India.

\subsection{Study Components and Methods}

Community-based assessment of natural resources, management practices, and policy analysis were the key components of the study. The study carried out in 2014-2016 took a cultural landscape/seascape approach to analyze land/resource-use linked differentiation of ecosystems, resource utilization/regeneration mechanisms, spatiotemporal dynamics of resources and livelihood and people's perceptions about climate change/ sustainability/policy interventions. Covering three villages for intensive observations, the study comprised three activities: (1) detailed ground survey of biophysical resources and their mapping by integrating information obtained from ground survey, participatory discussions, satellite imagery, available topographic/thematic maps and geographic information system; (2) socio-economic survey through structured questionnaire, open-ended interview, and focused group discussions to elucidate indigenous knowledge, community based management practices and people's perceptions about livelihood, state interventions and environment/development problems; and (3) identification of good land/resource use practices synergizing multiple benefits from coastal cultural landscapes/seascapes (Sein et al, 2015). Through multi-stakeholder consultations and dialogues, the policy analysis reviewed existing policies influencing community-based forest management. This analysis vis-à-vis the findings from the community-based assessments enabled identification of opportunities for better coastal forest management.

\section{RESULTS AND DISCUSSION}

\subsection{Adaptive Management and Best Practices}

The community-based assessment of coastal forests found out that local people in all study sites have long made efforts to establish plantation forests and to conserve natural forests around individual houses as well as the entire villages for protection from windstorms due to frequent typhoons or cyclones. Extensive mangroves are conserved and actively planted by villages with support from the government agencies as well as NGOs on the windward side of the coastal villages in the study sites of Myanmar and Philippines to mitigate impacts of the strong southwest monsoon. Many villages maintain man-made and natural mangrove belts at their boundaries facing river and seafront in the study sites of the Ayeyarwady Delta in Myanmar and the Indian region of Sundarban on the Bay of Bengal. Trees are systematically planted and maintained in the form of forest belts at the village boundary since centuries in the study site of Okinawa islands, Japan. The forest belts are much denser

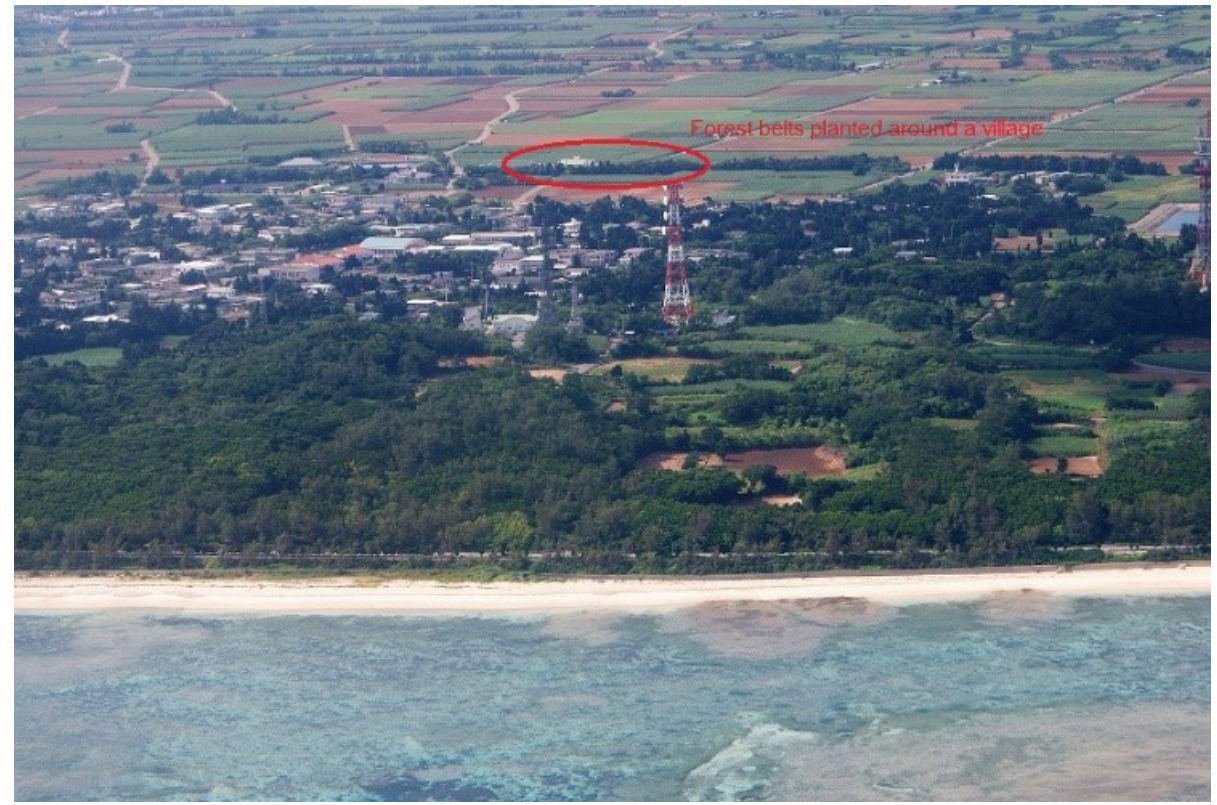

FIGURE 2. Forest belts of Garcinia subelliptica planted around Tarama village, Okinawa, Japan (marked in red circle) 
at places facing the coast or the north to cope with frequent and strong winds in Okinawa (Chen, et al 2008).

In addition to the protection forest belts around the village boundary, each household maintains a home garden distinguished by high density of trees (coconut, bamboo, betel nut, mahogany, etc.) forming the top canopy and a range of annual/perennial/seasonal crops in the understory for protection from strong storms and intense sunshine together with production of economic products in the study sites of Myanmar and India. Likewise, Fukugi trees Garcinia subelleptica resistant to windstorm are planted as a forest strip encircling individual houses in Okinawa for protection from windstorms and provide shade (see Figure 2). Protection from the forest strips is often augmented by establishing stone walls close and parallel to them. As a traditional best practice, protection forests are maintained both as family-managed units aiming protection of a given household and as a community-managed unit for protection of the whole village from windstorms in all study sites.

Apart from embracing forests for protection, local communities have designed houses taking into account risks of flooding and windstorm. Building houses on the stilts above normal flood water level is a traditional way of coastal communities in both the Philippines and Myanmar sites to reduce the risk of damage due to tides and frequent flooding of low-lying areas (see Figure 3). From the past few years, the traditional wooden stilts are being increasingly replaced by a concrete structure for its longer life, low maintenance costs and stronger resistance to flooding and windstorm. On the contrary, traditional houses in Okinawa are often built below the ground level in man-made depressions to minimize adverse impacts of windstorms (see Figure 3). Nevertheless, raised houses on stilts in the Ayeyarwady Delta of Myanmar and the Bohol Island of the Philippines is not a feature of Indian region of Sundarbans. Here, in almost all settlements, houses are either far away from the river/ seafront (beyond high tide) or by the side of an earthen embankment (opposite side of embankment facing river) lined by bricks and augmented or not by belts/strips of forest plantations. The embankment is high enough to protect from tides and floods but has succumbed at times to extreme flood events.

Sometimes, biological and physical methods are integrated to reduce risks of flooding (see Figure 4). Mangroves (Avicennia spp.: air-drop) are maintained towards riverfront, and Casuarina, Tamarix gallica, and Acacia are planted on the embankment as in the study site of India. Along the coasts of Okinawa, concrete seawall and structures are built to mitigate coast erosion. In the past and even today, monastery serves as cyclone shelters as their stilts are much taller than those of ordinary houses in the study site of Myanmar (See Figure 5). Cyclone shelters of the concrete structure on the tall stilts are also now established in schools. Early warning system is also important for local people to move to cyclone shelters in time when the coastal hazard is forthcoming. Therefore, local communities in study sites integrate both forests and physical structures in the protection of their houses and farms.

The man-made mangrove forests are the source of a range of economic products including fish, molluscs, crabs, honey, fuelwood, timber and thatching material and thus play very important roles in local livelihood in

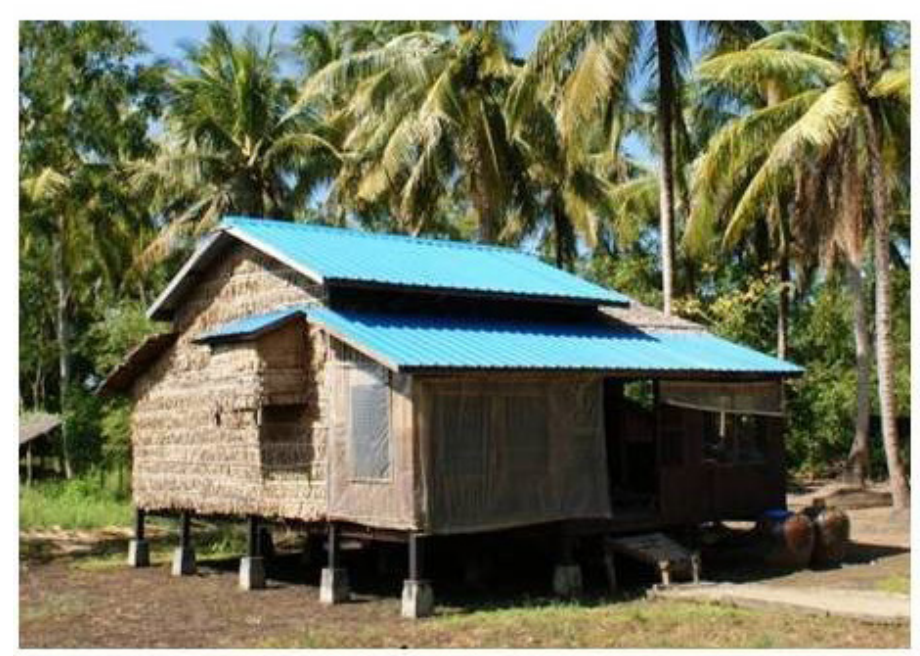

Raised house on stilts in Myanmar

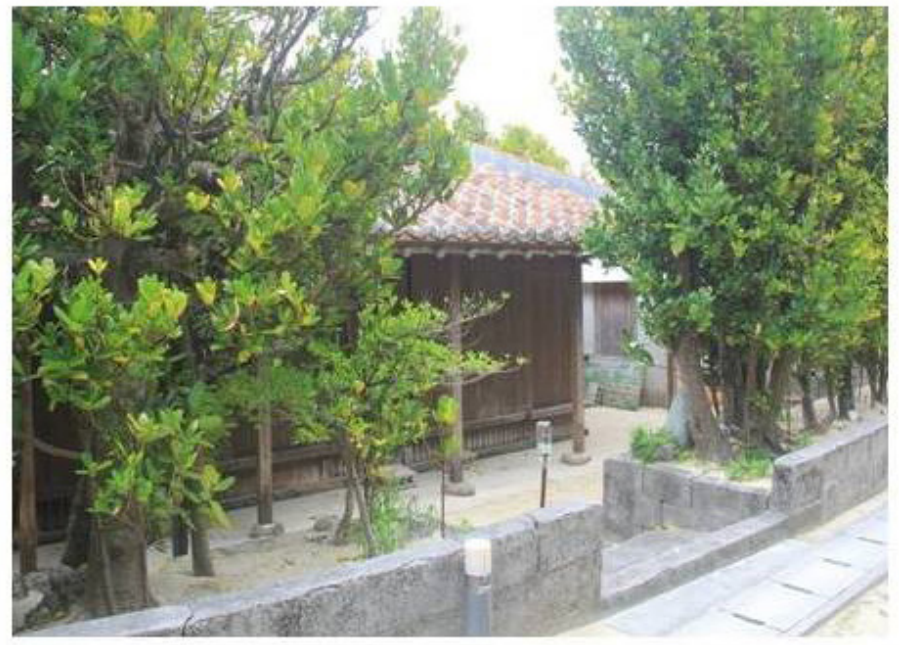

Lowered houses in depression in

Okinawa, Japan

FIGURE 3. Traditional houses are surrounded by forested home-gardens/strips in study sites of Myanmar and Japan. 

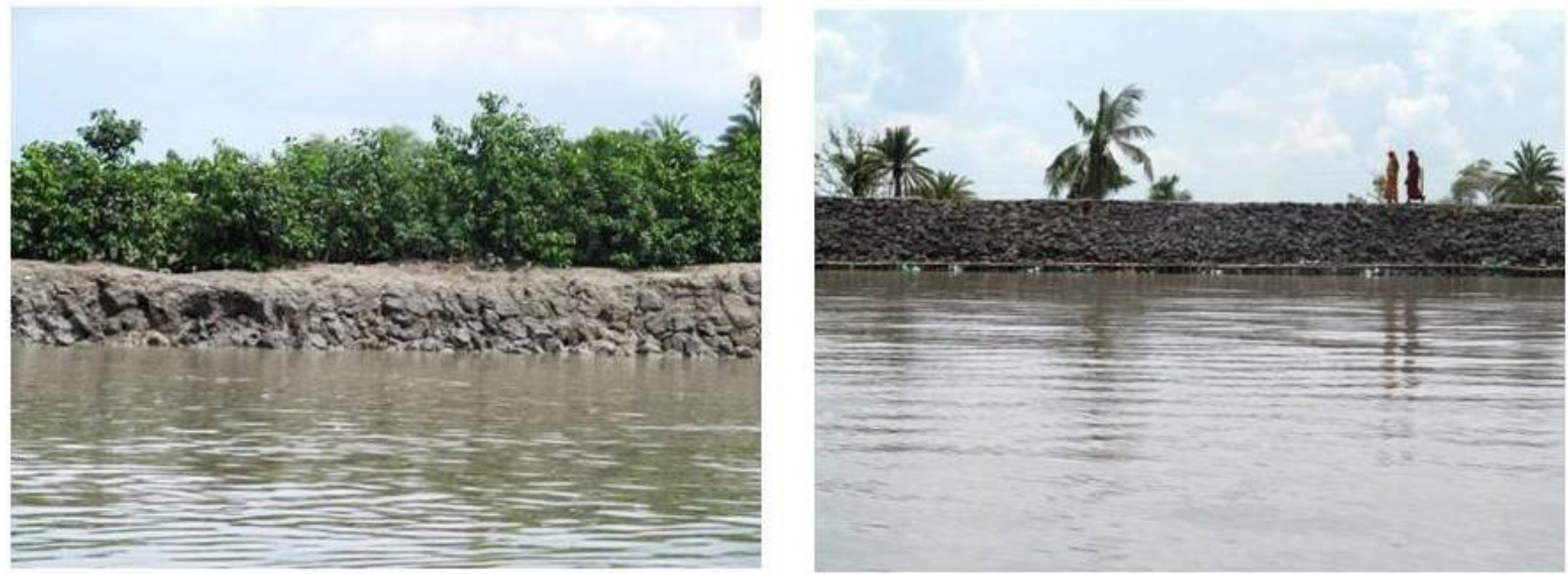

FIGURE 4. Forest belt and embankment are often integrated to reduce risk of flooding in the associate study site of Indian Sundarbans.

Myanmar, the Philippines and India in addition to their protection function. Sustainable use of forests is critical for coastal communities in Myanmar, the Philippines, and India. Coastal communities manage natural regeneration of nipa palm yielding high-quality thatching materials and nutritional fruits in the tidal zone and cultivate coconut, areca nut, and many other useful trees in tree-crop mixed home gardens developed on a higher ground beyond the reach of high tide in Ayeyarwady delta of Myanmar. Most home gardens are integrated with fish and crab ponds such that the ponds get enriched with run-off and lateral subsurface flows from the gardens, while irrigation from pond water reduces water and nutrient stress in home gardens. Ongoing efforts of mangrove rehabilitation contribute to both local livelihoods (such as the production of timber and fuelwood, non-timber forest products, and fish, crabs, and molluscs) and coastal protection. On the contrary, the manmade forest belts in Okinawa are mainly created for the

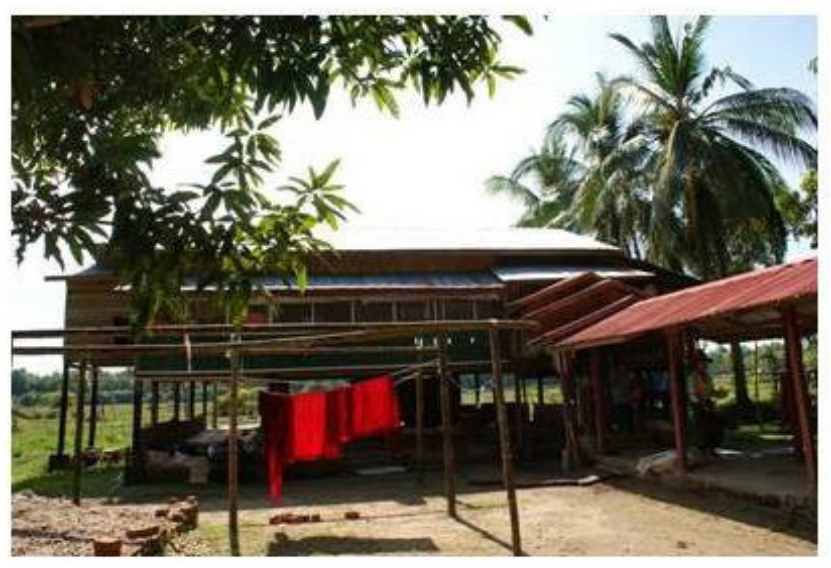

Monastery protection of houses and farms from strong winds and for cultural values of Fengshui that recognizes a closed landscape as an auspicious one. Nowadays, these traditional man-made forest belts have become attractions for cultural tourism.

\subsection{Issues and Options for Coastal Forest Management}

Traditional coastal communities evolved livelihood systems that met their subsistence needs by utilizing resources in the sea/river and mangroves in different stages of succession at the sea-land interface. Further, these sea-facing ecosystems with biological and physical modifications are used as a shield to protect crops/ livestock husbandry/aquaculture in the inland area from storm surges and flood. Such systems, common across countries, have location specificities and have been impacted in divergent ways by economic globalization, socio-political conditions, technological advancements and global environmental changes; a land/resource use

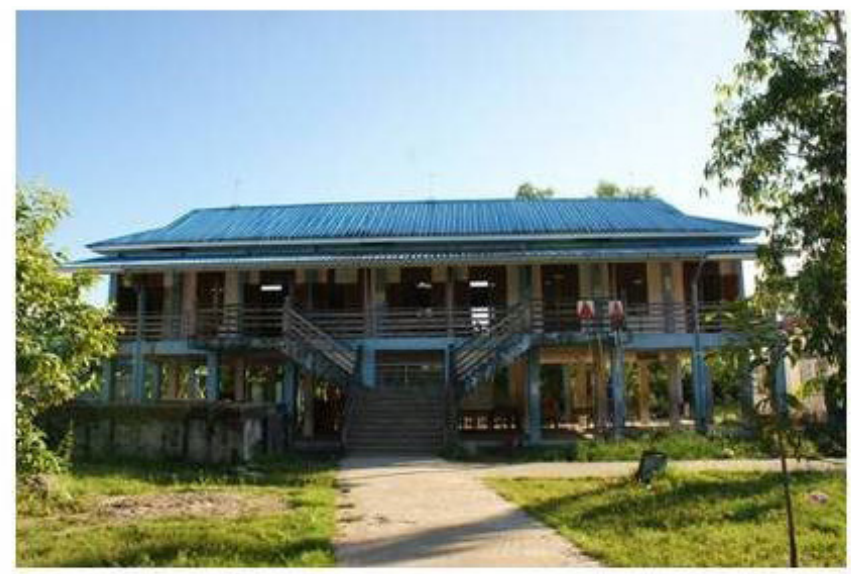

\section{School}

FIGURE 5. Monastery and school raised on the tall stilts could serve as cyclone shelter to cope with risk of floods in the study site of Myanmar. 
or landscape architecture traditionally considered the "best" earlier may not be the best one at present or in future. Thus, as seen in the Okinawa site, expansion of urbanization, industrialization, advanced technologies and outmigration after second world war reduced beach plantations and Garcinia subelleptica groves around individual dwellings led to decline in natural capital (carbon stock and biodiversity) and huge investment of physical and financial capital in modern engineering methods of protection from wind and cool temperatures. Though mere restoration of traditional forest cover may enhance biodiversity and mitigate climate change and enhance local livelihood from income from ecotourism in such unique cultural landscapes, lack of policies and proactive role of local government are the major bottlenecks in inducing such changes even in a developed country like Japan (see Figure 6).

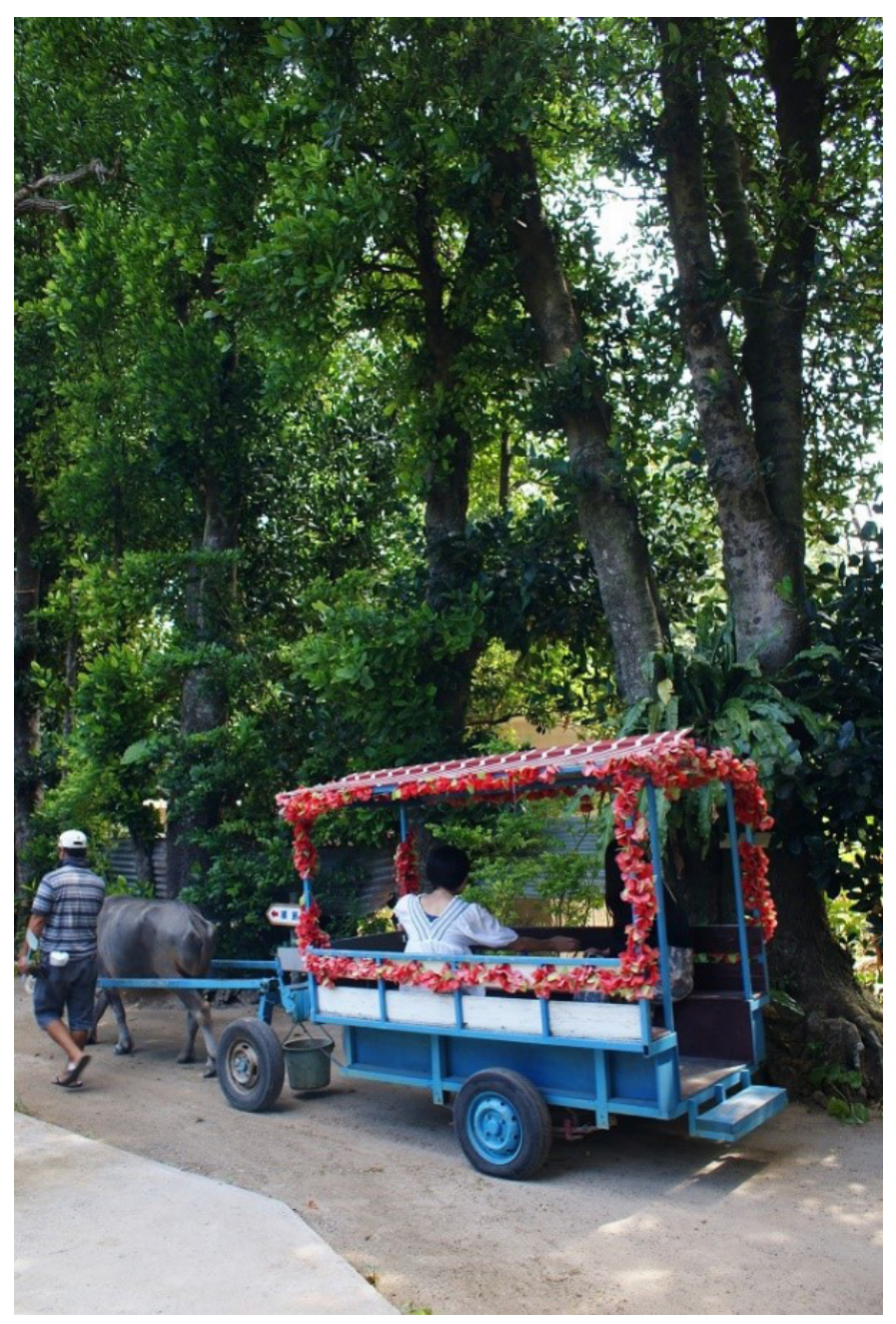

FIGURE 6. Garcinia subelleptica groves/belts are major attractions to tourists but management guidelines have not yet evolved in Okinawa, Japan.

In the Philippines, Tagbanua people utilized only dead trees for charcoal and fuelwood for a belief that healthy mangroves were necessary for sustaining fish production accounting in many locations $>80 \%$ of direct use value (Carandang et al., 2013). Huge dead wood is available as a result of frequent downing and uprooting following typhoons observed around Palawan and nearby islands ravaged by Typhoon Haiyan, a category 5 storm, November 2013. However, deadwood alone could meet the needs at a time when mangroves were extensive and population pressure was low. This "best practice" in low population- subsistence economy is no longer tenable in the present scenario when natural intact forests have almost vanished, income needs of people have dramatically increased, policy supports more efficient income opportunities from plantations and a higher resilience potential of mosaic of forest, farm and aquatic ecosystems than dependence solely on forest resources is getting more and more acceptance. Thus, leasing degraded state forest land to people in Community Forestry programme and incentives to private companies to extend financial support for plantation since the $1990 \mathrm{~s}$ is a good practice synergizing local concerns for immediate income and long-term global environmental benefits. However, the outcomes can be further improved by developing silvicultural practices enabling simultaneous enhancement of multiple functions of plantations, demonstrating them and facilitating their widespread adoption. Research is needed to determine sustainable limits of wood removals.

Homegardens in Ayeyarwady Delta of Myanmar and Sundarbans of India exemplify the potential of indigenous knowledge in establishing a land use as productive and rich in species and regulating services as natural forests by identifying micro-sites where salinity and water stagnation are avoided by a combination of physical, biological and ecological techniques. This traditional land use synergizing local livelihood concerns with global biodiversity conservation and climate change mitigation concerns, however, has been stagnant or declining in the absence of policies encouraging indigenous innovations and scientific research complementing/supplementing indigenous knowledge. Unlike widespread occurrence of home gardens, cultivation of Piper betel (betel leaf) is an indigenous innovation confined to only a couple of islands in Sundarbans. Betel cultivation has enhanced both social bonding (linkages within the farming community) and bridging (linkages between farmers and distant traders and consumers) enabling high profits from a perishable commodity produced solely by recycling and managing local resources and ecological processes. The high productive potential of betel garden is maintained by using sediments from fish ponds as manure and irrigating it by the water flushed out from these ponds for high fish production. Exposure to new management and production systems in areas visited primarily for the purpose of trading the local product like 
betel resulted in the cultivation of Sesbania rostrata to serve the twin purposes of reducing salinity and nutrient enrichment without any external financial or technical assistance.

People do understand detrimental impacts of overgrazing by livestock and intensive pruning for fuelwood, susceptibility of grazed/trampled/pruned trees to pests and pathogens, encroachments of degraded forests, and deforestation due to shrimp farming but find themselves helpless in restoring degraded lands and sustainable intensification of resource uses in intact forests due lack of required technical knowledge and investment capacity. The system of Regeneration Improvement Felling developed in Myanmar favouring mixed economic species over weedy growth developed for government forests is a good practice of coupling of concerns for income/ material benefits among local people and the global concerns for biodiversity conservation and enhancement of regulating service. Such systems have two times higher carbon stocks and plant species diversity than monospecific plantations established after clear felling and hence need to be encouraged through community forestry.

In situations like Sundarbans where deforestation/ forest degradation was not so rampant, bonafide residents enjoyed rights of free subsistence uses of forest resources even after the land was taken over by the government in the 1950 s and incentives for honey marketing necessitated fostered maintenance of healthy forested landscapes. Government authorities (i) organized groups of local people for honey collection from state forests, (ii) reduced the risks from the tiger by allowing collection only in groups, and (iii) secured income to farmers by procuring the products and then marketing it at no costs to farmers. Nonetheless, attention has not been paid to enhancement and replication of many good traditional practices : (i) integrated management of a highly heterogeneous landscape comprising paddy fields, fish ponds, home gardens, betel gardens and mangroves; (ii) lunar cycle of collection of fish, crabs and shrimp larvae; and (iii) creation of temporary ponds on river bank to collect dead wood/debris from mangrove forests in tidal flows, a labor-intensive but ecologically efficient way of meeting fuel needs. Coexisting with these good practices are unsound practices, like burning faecal pellets of goat, the dung of cattle (in the form of a cake) and coconut shells; the resource can be better used as manure.

Valuation of a species and process depends on the socio-ecological scenarios. Thus, palm Nypa fruiticans is a highly valued species in Myanmar but not in Sundarbans region of India because of better economic development alternatives. As this palm requires open areas for proper growth and reproduction, its high production is possible only at the expense of tree and herbaceous species and thereby reduction in carbon stocks.

\subsection{Policy Dimensions}

Policies in all the countries changed with changing imperatives of ecological, economic and social development. However, often different issues are dealt by different policy instruments at different times leading to confusions and contradictions. The Philippines government provides many incentives to Community-Based Forest Management (CBFM) but mangrove CBFM participants and other forest developers cannot avail them because of prohibitions enforced on felling through RA 7161 (cutting ban for all mangrove species especially for firewood purpose). It is necessary tore-zone coastal areas for local benefits (wood utilization and tourism) and global benefits (carbon offset and strict protection of biodiversity). Community Forestry Instruction (CFI) in Myanmar are heavily dedicated to technical efficiency and ecological functions of forests leading to neglect of livelihood enhancement function of forests and thereby adoption of unsustainable forestry practices by local people to secure better albeit short-term livelihood. It is urgent to formulate a proper land use plan for the Ayeyawady Delta for continued conversion and degradation of mangroves. Although windbreak function, biodiversity conservation and cultural dimensions of Garcinia subelleptica groves/ strips are well recognized in Okinawa, a local conservation ordinance is still not in place to regulate the management, especially cutting of old Garcinia subelleptica trees. Regional recommendations such as greenbelts with a minimum of width of $100 \mathrm{~m}$, but preferably up to $500 \mathrm{~m}$ or $1 \mathrm{~km}$ at the open coast, and $30-50 \mathrm{~m}$ along riverbanks and lagoons, and $>10 \mathrm{~m}$ on islands, creeks, and channels (Macintosh et al 2002; Ashton et al., 2004) should be analyzed in the local contexts, appropriately modified and adopted. There is a need for harmonizing multiple and divergent dimensions of forests and livelihood in a simplified, unified, clear and holistic national policy and guidelines on coastal zone management.

The study recommends that coastal forest policymaking must take into account indigenous knowledge and local concerns along with scientific knowledge and global concerns for coastal forest management. The globally recognized approach(es) ICZM (Integrated Coastal Zone Management) or ICRM (Integrated Coastal Resources Management) or ICM (Integrated Coastal Management) should be considered and followed.

\section{CONCLUSION}

Coastal landscapes are undergoing a variety of changes. With enormous variation in environmental and socio-economic conditions and interactions between 
forest, farming, aquaculture and sea/river systems, coastal forest management needs to be addressed as an integral component of cultural landscape/seascape rather than as a sectoral and independent activity. Further, forest conservation and restoration should be integrated at a regional scale. A participatory forestry is a good approach but, apart from empowering people by leasing land and granting funds, there is also a need of mobilizing people to apply and enhance indigenous knowledge unlike the present approach of following top-down prescriptions. Unlike a seawall which only has a protective function, coastal forests not only protect local communities from floods, tides, and storms but also provide a wide range of vital ecosystem services for global and local communities. Recognising multiple values of coastal forests, local communities have long conserved and planted forests around their houses and villages. Coastal forest policymaking must take into account local benefits and indigenous practices beyond global benefits and scientific knowledge. It is also necessary to further improve guidelines for rehabilitation and management of coastal forests for a wide range of ecosystem services.

Early, high and secured income from any occupation remains the top priority of people in poor countries. There is a need for setting out long-term participatory research to design management plans harmonizing local concerns for income/livelihood enhancement with global concerns for enhancing/conserving biodiversity and regulating and supporting functions of coastal ecosystems. Apart from participatory research in a given area, regional cooperation on research and capacity building may hasten the process of replication and further improvement of the known good practices within ICZM (Integrated Coastal Zone Management) or ICRM (Integrated Coastal Resources Management) or ICM (Integrated Coastal Management) frameworks.

\section{ACKNOWLEDGEMENT}

This article features results of the research project "Coastal forest management in the face of global change based on case studies in Japan, Myanmar and the Philippines", which was made possible through the ARCP Programme of the Asia-Pacific Network for Global Change Research (APN). The project team also appreciated the co-funding of the United Nations University Institute for the Advanced Study of Sustainability (UNU-IAS) and its "On-the-Job Research Capacity Building Programme for Food Security and Environmental Conservation in Developing Countries (OJCB)", the University of the Philippines Los Baños (UPLB), the Forest Research Institute (FRI), the University of the Ryukyus, the Jawaharlal
Nehru University (JNU), and the assistance of local communities and authorities in study sites of the Philippines, Myanmar, Japan and India.

\section{REFERENCES}

Alongi, D.M. (2008). Mangrove Forests: Resilience, protection from tsunamis, and responses to global climate change. Estuarine Coastal and Shelf Science 76: 1-13.

Alongi, D.M. (2012). Carbon sequestration in mangrove forests, a review. Carbon Management 3: 313-322.

Ashton, E.C., Ikejima, K. and Macintosh, D.J., 2004. Mangrove Ecosystem Management. Distributed Education Center, Asian Institute of Technology, Bangkok, Thailand. E-learning module. Code No. ED71.26. http://www.avist.org

Carandang, A.P., Camacho, L.D., Gevaña, D. T., Dizon, J. T., Camacho, S.C., de Luna, C. C., Pulhin, F. B., Combalicer, E.A., Paras, F. D., Peras, R. J. J. \& Rebugio, L. L. (2013). Economic valuation for sustainable mangrove ecosystems management in Bohol and Palawan, Philippines. Forest Science and Technology (2013): DOI: $10.1080 / 21580103.2013 .801149$

Chen, B., Nakama, Y. and Kurima, G. (2008). Layout and composition of house-embracing trees in an island Feng Shui village in Okinawa, Japan. Urban Forestry \& Urban Greening, 7 (1): 53-61

FAO (2007). The World's Mangroves 1980-2005. FAO Forestry Paper No. 153. Rome, Forest Resources Division, FAO. pp. 77.

Giri, C., Ochieng, E., Tieszen, L., Zhu, Z., Singh, A., Loveland, T., Masek, J. and Duke, N. (2011). Status and distribution of mangrove forests of the world using earth observation satellite data. Global Ecology and Biogeography 20: 154-159.

Macintosh, D. J., and Ashton, E. C. (2002). A Review of Mangrove Biodiversity Conservation and Management. Centre for Tropical Ecosystems Research, University of Aarhus, D

Saintilan, N., Wilson, N., Rogers, K., Rajkaran, A. and Krauss, K.W. (2014) Mangrove expansion and salt marsh decline at mangrove poleward limits. Global Change Biology 20: 147-157.

Sein, C. C., Oo, T. N., Win, B. N., \& Chen, B. (2015). Assessing different land use pattern and livelihood of the local people in the mangrove area (Case study in Pyapon Township). Global Journal of Wood Science, Forestry, and Wildlife. 3 (2), pp. 052-058

Spalding, M., Kainuma, M. and Collins, L. (2010). World Atlas of Mangroves. ITTO, ISME, FAO, UNEP-WCMC, UNESCO-MAB, and UNU-INWEH. Earthscan Publishers Ltd. London. 